\title{
1. Introducing critical policy discourse analysis
}

\author{
Jane Mulderrig, Nicolina Montesano \\ Montessori and Michael Farrelly
}

This volume presents ten empirical case studies that demonstrate the added value of integrating Critical Discourse Analysis (CDA) with Critical Policy Studies (CPS), producing a theoretical and methodological synergy we term Critical Policy Discourse Analysis (CPDA). ${ }^{1}$ Our aim is three-fold: first, to show how this integration can enrich the conceptualisation - and thus analysis - of policy; second, to render explicit the methodological steps whereby such analysis can be operationalised; and, third, to reflect on the distinctive contribution made to both fields when such an integrated approach is applied to actual policy problems. These aims are reflected in the way the chapters are organised. First, each chapter investigates a particular policy-relevant problem which was tackled using a critical discourse analytical approach, with a specific focus on detailed textual analysis. This latter focus reflects an important contribution of CPDA to policy research: namely, an analytical framework capable of capturing, and conceptualising in relation to their socially structuring potential, the fine details of text which are often overlooked in policy analysis, but which have effects on how policy is understood, developed, and implemented. Second, each chapter takes the reader through the methodological decisions made, while making explicit the underlying theoretical assumptions which motivated them. Finally, each chapter reflects on the novel theoretical and empirical insights which were born out of this integrated approach.

CDA is an approach to social scientific research which combines detailed analysis of texts with theoretically informed accounts of the phenomena under investigation, in order to identify the processes by which language (re)produces social practices and helps privilege certain ways of doing, thinking, and being over others. It investigates how language figures in the constitution, contestation, and transformation of social problems, and thereby processes of social change. $\mathrm{CDA}^{2}$ has its origins in linguistics and can best be seen as a problem-oriented interdisciplinary research movement, subsuming a variety of approaches, analytical models and research agendas (Fairclough 
et al., 2011; Farrelly, in press; for recent surveys see Wodak and Meyer, 2016; Flowerdew and Richardson, 2018, and for a critical comparison see Fairclough, 2015). Each variety of CDA is characterised by a focus on the linguistic dimensions of power, injustice, conflict, and change. CDA has been variously applied to the investigation of racism and discrimination, media and political discourse, democracy and governance. In this volume we make a case for its integration with policy studies, arguing that it offers rigorous and systematic text analytical tools with which to enrich critical policy research.

CPS is a well-established approach to policy research. Its origins, according to Torgerson $(2015$, p. 27 ), can be traced back to efforts, in the post-war era, to develop a critical and democratic policy science, and in particular the work of political and communication theorist Harold Lasswell. More recently, CPS has developed a distinctive profile in the field of politics and policy studies. It is characterised by a strong emphasis on the 'contingency' of policy formation and implementation, and:

an effort to understand policy processes not only in terms of apparent inputs and outputs, but more importantly in terms of the interests, values and normative assumptions - political and social - that shape and inform these processes. (Fischer et al., 2015, p. 5)

In addition, CPS emphasises the centrality of meaning-making practices in the production, implementation, and interpretation of policy. And this is where it offers a clear connection with the discourse approaches that are presented in this volume. CPS is characterised by a strong analytical focus on discourse as well as a rich contextualisation of the social settings in which policy is enacted and interpreted. It also recognises the limitations of positivist 'cost-benefit' analyses which view policy as an act of instrumental rationality imposed on particular 'targets', and instead calls for a dialogical, discursive turn capable of reconnecting policy analysis with participative, democratic goals (Fischer and Forester, 1993; Hajer and Wagenaar, 2003; Wagenaar, 2011; Yanow, 2007). Concerns in CPS include:

theoretical and empirical work on discourse analysis, policy deliberation, deliberative democracy, citizen juries and consensus conferences, participatory governance, and the politics of expertise, as well as participatory policy analysis and collaborative planning, local and tacit ways of knowing, interpretive and ethnographic methods. (Fischer et al., 2015, p. 5)

The work included in this volume aims to contribute to the development of these concerns in its explication of the specific theories and methods associated with CDA and political discourse analysis. In this volume we use the term CPS to characterise those post-positivist approaches to policy research which 
highlight the importance of investigating the role of language, beliefs, and values. They form part of the 'cultural' or 'ideational' turn in political science, which regards semiosis ${ }^{3}$ as having causal powers in social life (Fairclough et al., 2004). It thus follows that its analysis helps not only to interpret but also explain the processes through which policy is understood, developed, and implemented. This emphasis on the interpretive and explanatory gains to be had from taking semiosis seriously in policy research is most clearly captured in the term Interpretive Policy Analysis (IPA). In fact, the distinction between IPA and CPS is somewhat porous and a matter of emphasis. Both can be used to characterise post-positivist approaches to policy research, and the theoretical developments which these have brought. The former term helps focus attention on the 'ideational' turn this has involved and the concern with investigating the ways in which 'meaning' shapes policy and politics. Influenced by hermeneutic, phenomenological, and ethnological philosophical traditions, this recognises the significance of intersubjective meaning-making among discourse communities and the prior knowledge, values, experience, and so forth they bring to policy-relevant processes (Bevir and Rhodes, 2002; Yanow, 2014). Alongside these ontological assumptions and emancipatory goals, the term CPS is a reminder of the equal significance of normative and explanatory critique in policy research. For the purposes of this volume, we embrace these theoretical and practical advances, as part of the 'argumentative' or 'ideational' turn in policy research. For the sake of convenience and simplicity, we characterise research in this field under the label CPS.

In 2003 two key texts were published, which crystallised for the policy studies community the growing importance and theoretical contribution of post-positivist approaches to political science which had emerged towards the end of the C20th. Frank Fischer's 'Reframing Public Policy' conceptualises policy as a discursively mediated process of problematisation and deliberation, and highlights the role of interpretation, narrative analysis, and argumentation in policy analysis. At the same time, in 'Interpreting British Governance' (2003), Bevir and Rhodes argued that an interpretive approach is essential, since we cannot understand political practices without reference to the beliefs, values, traditions, and responses to dilemmas, of the people involved. Their approach emphasises the explanatory importance of narrative and historical analysis in political science. Both texts thus introduced a distinctive shift away from the positivist approaches which had dominated Anglophone political science, which saw politics as a closed system and the objective of the analyst to explain outcomes in terms of the operation of structural forces like institutional path-dependencies. Influenced by hermeneutic traditions in sociology and anthropology, this ideational turn in policy studies brought recognition of the valuable insights to be had from interpretive approaches like ethnography, whose 'thick descriptions' yield access to the meanings which 
particular actions have for social actors (Bevir and Rhodes, 2002; Yanow, 2014; Wagenaar, 2011). However, as Hay (2004) observes, this also has the disadvantage of severing questions of causality or explanation from meaning and interpretation, a link which CPDA seeks to reconnect by moving from detailed analysis of situated meanings to historically informed explanatory critique of why certain meanings achieve hegemonic dominance in specific contexts. A further source of influence has been poststructuralist and postmodernist philosophy, which poses powerful epistemological challenges to behaviourism and the theoretical underpinnings of positivist political science. Of particular influence was Michel Foucault's exposition of the role of discourse and meanings in shaping social practices, regimes of power, and ultimately individual subjectivities. His work is also taken up and operationalised through close textual analysis in CPDA. Poststructuralist discourse analysis brought a perspective on hegemony to CPS. It was originally developed by Laclau and Mouffe (1985/2001) and further elaborated within the 'Essex School' of Discourse Analysis (Glynos and Howarth, 2007). Discourse theory is noted for its radical materialist ontology, hegemony-based theory of political identity, and its plea for radical democratic politics (Van Brussel et al., 2019). A further important development within this 'ideational turn' in political studies has been a specific emphasis on argumentation and deliberation, rather than merely the insights (via narratives) of policy actors themselves. For instance, Fischer (2007) argues for the systematic investigation, at various levels of context (from the situational to the societal and ideological), of practical argumentation in order to develop a framework for evaluating policy (see also Fischer and Forrester, 1993; Fischer and Gottweiss, 2012). Finlayson's Rhetorical Political Analysis similarly emphasises the importance of analysing deliberation, and particularly foregrounds 'the intersubjective, dynamic, formation and reformation of arguments and the elements of which they are composed' (Finlayson, 2007, p. 560). Further contributions to CPS have also come from the development of cultural political economy (Jessop, 2004, 2010; Sum and Jessop, 2015), which focuses on how the relations between semiotic and extra-semiotic forces influence the selection and retention of certain imaginaries and strategies over others.

A key challenge in CPS has been to develop a systematic mode of inquiry which is sufficiently sensitive to matters of signification. Researchers have variously turned to framing theory, metaphor and narrative analysis, poststructuralist discourse analysis, ethnographic methods, and actor-network theory in the search for analytical models capable of examining the complex discourse dynamics which underpin policy. Indeed, largely because of its insistence on the centrality of discourse, CPS continues to search for a satisfactory integration of theory and discourse analytical method. To date, only a few books on methodology have been developed (Yanow, 2000, from a broadly interpretiv- 
ist point of view) and two handbooks (Bevir and Rhodes, 2016 from the perspective of interpretive approaches to political science; Fischer et al, 2015 on CPS). These texts offer valuable insights on how to perform fieldwork through interviews, observations and other methods, but so far have not developed these in terms of a thoroughgoing empirical study linked to both explanatory theory and operational methods (Wagenaar, 2011, p. 9). Wagenaar lists a series of concrete obstacles to performing interpretative policy analysis (2011, pp. 8-10). These include the complexity of creating a solid research design capable of supporting a critical, emancipatory approach to policy research. As mentioned above, CPS tends to rely on a vast array of different theoretical approaches, which draw on diverse epistemological and ontological assumptions, and which often contradict or even exclude each other. Furthermore, these approaches often fail to develop a clear methodological programme, instead offering rather abstract examples to illustrate how these theoretical approaches could be applied to research. This, of course, leaves the researcher rather empty handed when it comes to putting CPS into practice in an actual research project. The result is that much work performed in this tradition reconstructs these practices by dwelling too much on theory, without connecting theoretical insight to an effective methodology which could then mediate between theory and empirical data. According to Wagenaar, this problem also exists in both poststructuralist analysis and CDA (Wagenaar, 2011, pp. 7-10). For the application of CDA to policy analysis, specifically, Wagenaar suggests that 'it is remarkably difficult to translate [conceptual work on CDA] into clear-cut methods' and suggests that this is due to a 'certain ambiguity of purpose' in CDA and to the 'sheer wealth of concepts' available in CDA (Wagenaar, 2011, p. 165). The aim of this volume is precisely to address these criticisms by demonstrating a fully integrated and methodologically explicit approach to CPDA.

We argue that CDA is an ideal candidate for integration in CPS for two main reasons. First, CDA has developed a framework for conducting systematic, yet contextually sensitive, analysis of texts based on a critically grounded theory of discourse. Its abductive, multi-layered research methodology involves continual movement between theory, method, and data, allowing the researcher to link macro social processes to micro discursive events such as texts or conversations. Second, it shares with CPS a number of important assumptions about the object of research, as well as epistemological, ontological, and normative principles, which in turn have implications for how research can and should be conducted. The case studies presented in this volume explicitly discuss the research methodology, problems encountered, and rationale for the analytical decisions made. As such, we hope they make a significant and highly practical contribution to the field of critical and interpretive policy studies. 
Both CPS and CDA conceptualise policy as resting on political 'imaginaries', ${ }^{4}$ the discursive simplification of an infinitely complex terrain of political action, and the assumed landscape of possibility for government intervention. They thus construct a particular version of the problem, legitimated on the basis of available expert evidence, and are shaped by the dominant mode of governing (Hay, 1996; Jessop, 2002; see also Farrelly, Chapter 1). For this reason, both CPS and CDA work with the assumption that the language of policy plays a significant role in conceptualising the policy problem in specific ways and in legitimating the solution(s) it proposes (Fairclough, 2013; Fairclough and Wodak, 2008; Finlayson, 2007; Fischer, 2003). At the same time, it plays a role in the ongoing negotiation and co-constitution of subjectivities and practices of the wider socio-economic order, and for this reason warrants critical scrutiny. Discursively construing the politically possible and desirable with respect to a policy problem is a necessarily reductive process, potentially limiting what can be said and thought about the social practice in question. It is also a contingent process, dependent on the relational interplay between social strategies and their strategically selective context (Jessop, 2002). Indeed, no political programme carries guarantees of success. And it is precisely because of this fact, and the concomitant need for those programmes to be legitimated, that CDA can play a valuable role in policy analysis, using detailed textual analysis to reveal the linguistic mechanisms by which semiosis contributes to 'the overall constitution of specific social objects and social subjects' (Jessop, 2004, p. 160). This view of policy stems from certain theoretical assumptions in CDA and CPS.

Both reject positivist modes of analysis in favour of a critical, socially grounded approach to analysis (Bevir and Rhodes, 2002; Fairclough, 2003, 2015; Fischer, 2003; Reisigl and Wodak, 2016). It thus follows that both are firmly empirical, analysing policy in its actual social setting and embracing the perspective of the social agents involved, hence the interest in ethnographic methods (Schatz, 2009; Wodak, 2009; see also Savski, Chapter 9, on how to overcome problems of access). Both share an explicitly emancipatory agenda, highlighting the ideological workings of policies, rendering explicit hidden interests and the unequal distribution of social good. Both thus view the research process as a form of praxis, seeking to bring about positive social change (Wagenaar, 2011; Fairclough, 2015 pp. 14-15; Fairclough and Graham, 2002). In both cases this involves a reflexive and abductive methodology, continually moving back and forth between theory, method and data in order to achieve 'explanatory adequacy' in the research process (Montesano Montessori, 2011; Mulderrig, 2015; Wodak 2009; Yanow, 2014). This involves a movement from normative critique of discourse to explanatory critique ${ }^{5}$ of discourse as one element of social change (Fairclough, 2005, 2015). Research begins with a (partially conceptualised) problem and, through the critique of relevant texts 
(in the broadest sense of semiotic artefacts), seeks a theoretically informed account of the existing social and political economic conditions which explain why they took that particular form, thereby offering a basis for intervention to change those conditions. The researcher enters the hermeneutic circle of a multi-layered, iterative methodology whose 'requisite openness' (Yanow, 2014, p. 145) enables concepts and novel insights to emerge (for an example using corpus methods, see Mulderrig, 2011). A key outcome of this process is a 'mapping' of the research objects and settings in which policy is formulated and enacted. In CPS, for example, this is conceptualised as the linkages created through intertextuality ${ }^{6}$ (Yanow, 2014), while in CDA it is more fully articulated within a discourse analytical framework which views social events and texts as constituted within 'orders of discourse', a concept which captures the regulative and (re)productive capacities of semiotic practices (Fairclough 2005; Farrelly, in press; see also Mulderrig, Chapter 3). Indeed, we argue that CDA has much to offer CPS, not least in relation to how discourse is conceptualised and operationalised as method.

While the analytical focus of CDA is semiosis in its various forms (language, visual images and so forth), its critical stance implies a concern with the interconnectedness of these language practices with the values, beliefs, institutional structures, and vested interests of the wider social order (Fairclough et al., 2011). Its critical realist ontology makes explicit the dynamic and mutually constitutive relationship between discourse and other non-discursive elements of social practices (like beliefs, values, institutions, social relations, the material world, and power). Language internalises and is internalised by these other elements (Harvey, 1996; Chouliaraki and Fairclough, 1999). It follows that policy analysis must recognise the socially structuring potential of discourse without reducing policies to 'mere signification' - rather, policy discourses, objects, and actions are co-constituted and co-evolve in wider networks and social relations (in education policy, Mulderrig, 2009). Moreover, processes of social change can only be explained in terms of the strategic relational interplay between social practices (and the social structures which lie behind them) and social agents (see Fairclough et al., 2004, on the critical realist view which underpins this formulation). In order to capture this relationship, CDA has developed conceptual categories which remind us that texts do not exist in a social vacuum but instead form part of a process through which discourse both structures and enables social life (Fairclough, 2003; Wodak and Meyer, 2016). CDA recognises that hegemonic practice and struggle, to a substantial extent, take the form of discursive practice which naturalises particular relations and practices. It thus incorporates theories of power and ideology, using text analytical concepts like presupposition and intertextuality to trace the processes whereby certain discourse conventions become naturalised. CDA offers a powerful tool for the detailed analysis of texts: a sociologically 
grounded theory of language and semiosis (Halliday and Matthiessen, 2014; Van Leeuwen, 2008; Kress and Van Leeuwen, 2001) permits the systematic analysis of semantic, syntactic, and discursive relations within texts, while global patterns and relations between texts can be investigated through the analysis of intertextuality (Farrelly, 2019; Reisigl and Wodak, 2001) and interdiscursivity (Fairclough, 2003; Palma Carvajal, Horrod, Mulderrig, Poutanen, this volume). The breadth of work carried out within this field is captured in its key journals Critical Discourse Studies, Discourse and Society, Journal of Language and Politics, and in a growing body of methodology texts (for example, Bartlett, 2014; Fairclough, 2003, 2015; Fairclough and Fairclough, 2012; Lemke, 2005; Machin and Mayr, 2010; Reisigl and Wodak, 2001; Wodak and Meyer, 2016; Wodak and Krzyżanowski, 2008). However, while these offer a valuable resource for newcomers to the field, methodology is often demonstrated through illustrative excerpts selected to fit the method. Moreover, while such volumes highlight the importance of interdisciplinarity in CDA, in order to adequately explain and contextualise the social problem under investigation, this is often dealt with in the abstract. Consequently, it is not always clear to the researcher precisely how to operationalise CDA when faced with a real and unique social problem to investigate. This volume aims to address this problem by presenting a diverse set of empirical case studies which render explicit the methodological decision-making processes, as well as the rationale for working with particular social theories in order to contextualise and conceptualise the particular problem under investigation. The issues examined in the chapters cover a variety of policy issues and scales including education (Horrod, Palma Carvajal), health (Mulderrig), language and energy policy (Savski and Farrelly respectively); fiscal and economic policy (Theine and Rieder); labour policy (Caterina); and local fishing rights (Bartlett); case studies which span ten countries from South America to Northern Europe.

In summary, we argue in this volume that the integration of CDA with CPS has the potential to complement and enrich research in this field. Given the importance of language as an instrument of power and control, CPDA offers a tool in strategies of resistance. It provides a theoretically informed language of explanatory critique, capable of showing not only how, but why, the language and logic of neoliberalism comes to dominate and colonise even those voices which ostensibly stand in opposition to it (for example, Palma Carvajal, Chapter 5). It exposes the vested interests behind policy initiatives and thus challenges their neutrality and inevitability. It points to the contradictions inherent in policy and thus the fissures in strategies of hegemonic dominance.

We begin this endeavour by schematically outlining the key approaches ${ }^{7}$ which have developed within CDA. These share many properties, including the critique of discourse as practised in real social settings and an emancipatory motivation. However, there are also some important internal distinctions 
which merit elaboration. In our discussion, we focus in particular on the approaches which we see as having the potential to contribute more widely to CPS and which are operationalised in the case studies outlined in this volume (see Flowerdew and Richardson, 2018, for a more comprehensive overview of critical discourse studies). For those unfamiliar with CDA, we provide a brief glossary of key concepts used in these approaches, which the reader will encounter throughout this volume. Finally, we explain the structure of the remaining volume.

\section{THE DISCOURSE-HISTORICAL APPROACH}

This particular approach was developed in Vienna, initially to analyse anti-Semitic discourses in the 1986 presidential campaign of Kurt Waldheim (Reisigl and Wodak, 2001), and indeed has retained and refined a focus on right-wing discourse and discrimination (Wodak, 2015). Scholars working in the Discourse-Historical Approach (DHA) have developed a series of taxonomies with which to analyse a range of discursive strategies including 'nomination', 'predication', and 'argumentation' (see Reisigl and Wodak, 2016, p. 33; Horrod, Chapter 4). It emphasises the importance of historical contextualisation and triangulation of data, as well as the practical application of results, particularly in generating advice on developing better discourse practices (Reisigl, 2018). DHA is thus consequently also noted for its incorporation of ethnographic methods (see, for example, Wodak, 2009 on the European Parliament) and is operationalised through a series of steps, moving from macro to micro analysis of the problem under investigation, and has been extensively applied to problems of discrimination and social exclusion. Analysis includes a global content analysis, the analysis of argumentative and discursive strategies, and close textual analysis (Reisigl and Wodak, 2001). Examples of its use can be seen in the chapters by Horrod, Montesano Montessori, Palma Carvajal, and Savski.

\section{THE DIALECTICAL-RELATIONAL APPROACH}

This approach to CDA was developed at Lancaster University (Fairclough 1989, 1992, 1995, 2003, 2005, 2015; Chouliaraki and Fairclough, 1999), with a later specific focus on argumentation (Fairclough and Fairclough, 2012). This approach rests on a dialectical-relational theory of discourse (Harvey, 1996), in which it is seen to internalise other elements of social practice (actions, relations, objects, social subjects and their values, beliefs, and so forth). It thus strongly emphasises the socially constituted and constitutive properties of discourse. Its critical realist ontology (Bhaskar, 1986; Fairclough et al., 2004) influences its analytical categories and research goals. This approach 
thus aims to go beyond the normative critique (of problematic discourse) to explanatory critique, which asks what social and ideological conditions gave rise to those discourse practices in the first place, and thereby suggesting the basis for a transformation of those practices. In order to achieve this goal, it is committed not just to interdisciplinarity, but to transdisciplinary engagement with other disciplines, putting the logic and categories of other disciplines to work in developing one's theoretical and methodological framework. Social events are viewed as forming part of social practices; in their discursive aspect these are seen as a specific configuration of genres, discourses, and styles, or 'order of discourse' (Mulderrig, Chapter 3, presents a transdisciplinary framework for analysing orders of discourse). The approach is influenced by critical theory, Marxism, Hallidayan systemic functional linguistics, and has close ties with cultural political economy (Fairclough, 2013; Fairclough et al., 2004). In this volume, it is used by Caterina, Farrelly, Montesano Montessori, Mulderrig, and Poutanen.

\section{THE SOCIOSEMANTIC APPROACH}

Theo Van Leeuwen $(1995,1996,2008)$ developed a taxonomic model for analysing how social practice is represented in both linguistic and visual modes of communication. This has been widely adopted in CDA (for example, Fairclough, 2003; Farrelly, 2015; Machin and Mayr, 2013). According to Van Leeuwen, 'sociological agency is not always realised by linguistic agency'; he argued, therefore, that CDA ought not to tie itself too closely to linguistic categories like nouns, verbs, and clauses. His system of analysis posits instead 'sociosemantic' categories like 'personalisation vs functionalisation' or 'inclusion vs exclusion', which bridge the gap between linguistic and sociological agency in order to account for 'how the participants of social practices' can be represented 'in English discourse' (Van Leeuwen, 2008, p. 24). This approach can take analysis beyond the surface-meaning of word choice (as important as that may be) to uncover more implicit aspects of representation. Following a similar approach, he also developed a framework for analysing legitimation strategies in discourse (Van Leeuwen, 2007). Farrelly, Chapter 7, describes the operationalisation of Van Leeuwen's approach and its application can be seen in the chapters by Bartlett, Mulderrig, Poutanen, and Theine and Rieder.

\section{TERMINOLOGY AND CONCEPTS}

In order to orient the reader unfamiliar with CDA, we define some of the technical concepts used in this volume. 


\section{Text}

Any instance of semiotic practice (linguistic, visual, or aural), extracted from its context of production for the purposes of analysis.

\section{Discourse}

The process of social signification using a range of semiotic modes (language, image, sound) in a specific socio-cultural setting. From an ontological perspective, discourse is seen in CDA as one element of social life which is dialectically related to other non-discourse elements (like time, space, place, social power, and so forth). Operationalised in analysis, discourse is the patterned use of language which emerges from engagement in social practices. It thus reflects and helps to shape social practice.

\section{Orders of Discourse}

CDA (Fairclough, 1989, 2015) adapts this term from Foucault in order to capture the socially constitutive and regulatory power of discourse. An order of discourse is the distinctive configuration of styles, discourses, and genres that are routinely drawn on as part of a social practice. These help structure or 'order' that practice, discursively shaping its characteristic features, and connect it to networks of social practices, through links which can be analysed in terms of interdiscursivity. Such interdiscursive links between social practices are an essential feature of societies. They are also the engine of social change and a vehicle of power whereby certain social practices and their logics, values, and relations (for example, those of free market capitalism) come to dominate or 'colonise' others (for example, the delivery of public services).

\section{Interdiscursivity}

A text may be simultaneously analysed in terms of its distinctive configuration of genres, discourses, and styles, or its interdiscursivity. This concept allows us to capture the 'porous' nature of discourse through which it incorporates diverse elements of its wider social context and therefore to investigate the role of discursive change in driving social change (Fairclough, 2003, 2005). For instance, the 'managerialisation' of public services (Pollitt, 1990; Newman and Clarke, 1994) or 'marketisation' of political discourse (Pearce, 2004; Mulderrig, 2012) is essentially the result of the discourse practices of one field infiltrating those of another. 


\section{Intertextuality}

Intertextuality is a key analytical concept in CDA. It refers to 'the presence of actual elements of other texts within a text' (Fairclough, 2003, p. 39). This presence 'links' one text to another and the manner in which a text links to another is an important expression of the type of relation that holds between texts. Clear instances of intertextuality are direct and indirect quotation; Farrelly (2019) offers a detailed account of how it can be analysed in texts. He argues that by mapping 'meta data' on 'inter-texts' across a social practice we can chart relations within and between practices and networks of practice.

\section{THE STRUCTURE OF THE BOOK}

In Chapter 2, Nicolina Montesano Montessori describes a method of Text Oriented Discourse Analysis (TODA) applied to an analysis of the Zapatista movement in Mexico, in protest at the former Mexican president, Salinas de Gortari (1988-1994). Drawing on Fairclough's (1992) dialectical-relational approach, which aims to 'to put Foucault's philosophy to work' through detailed textual analysis, she brings together 'macro' and 'micro' aspects of social analysis, in order to reveal links between texts and their socially structuring contexts. This approach reveals the underlying structure of a text, and the range of implicit values and assumptions it relies on. It furthermore allows for the analysis of shifts of meaning in time; the historicity of texts. It also reveals the workings of power and ideology in discourse. The chapter explains in detail how to work with TODA, how to prepare research by creating a scientific object which entails selecting the relevant theory and methodology, as well as selection and preparation of data. She demonstrates the procedure step by step, by means of the Mexican case study, drawing on both CDA and discourse theory, a Gramscian approach to hegemony and a narrative theory developed for the social sciences. The chapter then reflects on the outcomes and reasons why a TODA approach is helpful for IPA/CPS researchers.

In Chapter 3, Jane Mulderrig investigates the increasing popularity among policy-makers of behavioural economics (or 'nudge') as a technique for subtly steering individuals towards more policy-compliant choices, and critically assesses its role in sustaining the neoliberal political consensus in the post-crisis austerity period. Its application to policy is illustrated through a case study looking at the UK government's 'Change4Life' campaign targeting childhood obesity. The chapter proposes a transdisciplinary framework for analysing the discourse of neoliberal governance, which operationalises Lemke's governmentality-framed critique of neoliberalism (Lemke, 2012) through the text analytical categories of CDA developed by Fairclough (2003, 2015). By analysing orders of discourse, she shows how policy is variously 
shaped by the relations, values, interests, and logics of a range of social practices, including those responsible for creating the policy problem in the first place. Using multimodal analysis, she examines the full range of modes (visual design, sounds, and text) through which this policy intervention is realised. Her findings reveal how this policy individualises responsibility for wellbeing and subtly blames feckless working-class lifestyles, while obfuscating the political economic conditions which produce socially unequal health outcomes. This chapter offers a transdisciplinary model for analysing contradictions and tensions inherent in the fine detail of specific policies, while at the same time revealing their wider role in producing neoliberal governance practices and shaping the kinds of resilient, self-disciplinary subjectivities they require.

In Chapter 4, Sarah Horrod takes a case study from a particular university to investigate the ongoing expansion and marketisation of the UK higher education sector. Bernstein's sociology of pedagogy is brought into dialogue with the DHA to examine how recent policy reforms are recontextualised within institutions and received by practitioners. To this end, she critically examines policy texts from the Higher Education Academy which introduce as educational priorities the themes of employability, partnership, assessment, and internationalisation. She then traces their implementation as institutional practices related to learning, teaching, and assessment. Finally, interviews with students and lecturers are used to gain insights into local sense-making practices. She focuses on the discursive construction of 'community', including a partnership between teachers and students, and how this concept is used in policy discourse to legitimate new approaches to learning and teaching. At the same time her analysis reveals a deficit model underpinning policy of outdated teachers reluctant to embrace change, while construing students as partners in order to offer a solution to the potentially damaging discourse about 'students as consumers'. By incorporating ethnographic methods in her research, however, she is able to show how these pedagogic identities construed in policy are challenged by the reality of how teachers and students actually see themselves.

Chapter 5 also explores the field of education policy, this time in the context of post-Pinochet Chile. Juan Francisco Palma Carvajal combines a DHA with Foucault's theoretical work on governmentality to investigate the extent to which two Non-Governmental Organisations (NGOs) involved in education policy-making are influenced by, or offer resistance to, neoliberal ideology. Extensive neoliberal reforms were forcibly imposed on the Chilean state, economy, and social policies during the Pinochet dictatorship (1972-1990), and thereafter remained hegemonic until the student protests of 2006 and 2011, which demanded the return of free, public education. The two NGOs, fictitiously ${ }^{8}$ named 'Changing Education' and 'Time to Teach' were created after the protests of 2006, calling for greater equity in the education system 
and better working conditions for teachers. The analysis investigated the framing and diagnosis of the crisis in policy documents from each NGO, opinion pieces in Chilean newspapers, and governmental policy papers. Findings revealed that both NGOs, in different ways, are in fact colonised by the neoliberal system they supposedly seek to challenge; both are focussed on the manipulation of agents - whether to improve their professional excellence or to become agents of change - while leaving the underlying socio-political structure unchallenged.

Chapter 6 examines the rise and fall of Nokia in Finland and the impact of neoliberal business discourse on public media discourse. Mikko Poutanen's analysis starts from the observation that the state had all but vanished from the centre of Finnish public policy discourse in the 2000s (Hellman et al., 2017). However, rather than debating and arguing for this shift explicitly, Poutanen argues, it was gradually implemented with the help of the pro-market arguments found in the media and adopted more widely in public discourse. The chapter shows how the Finnish media seems to have been prepared to accept the market-centred conceptualisation of society. The chapter presents analysis of a corpus of Finnish print media articles using the work of Fairclough and Fairclough (2012) as a basis for his analysis of argumentation in these articles. Given Nokia's evident success, it became standard reasoning in public argumentation and in public policy that what was good for Nokia was also good for Finland. Poutanen shows how media argumentation in the case of its reports and commentary on Nokia promoted a pro-market view of economic policy that ran into serious problems as Nokia's downward spiral began, followed by the financial crisis also hitting Finland.

In Chapter 7, Michael Farrelly shows how analysis of the textual representation of social actors (Van Leeuwen, 1996, 2008), in dialogue with cultural political economy (Sum and Jessop, 2013) can give valuable insight to the conceptualisation of objects of governance. The case study examines the historical shift in UK policy on the governance of its gas industry from state ownership and control to shareholder ownership and the 'control' of 'market discipline'. The analysis focuses on the conceptualisation of 'competition' during two key parliamentary debates. The chapter points out that, before privatisation and marketisation, the UK gas industry had become a world leading industry with the capacity to plan and deliver major infrastructure projects, sell gas to domestic consumers at a low price and return large sums of money to the national treasury. In the wake of 'competition', however, 'concerns have arisen in relation to the affordability of energy' (CMA, 2016, p. 2), and low rates of consumers regularly switching supplier (Ofgem, 2017, p. 6). A 'competitive' system would require a critical mass of 'competitors' and 'active' consumers to apply competitive pressure on those competitors. However, the analysis shows that the 'consumer' was invariably represented in a passive role during 
the parliamentary debates and that on only one occasion in the data did the lead minister refer to the competitors upon which the new system was predicated.

In Chapter 8, Hendrik Theine and Maria Rieder combine a critical discursive approach with cultural political economy to analyse the media reception of Thomas Piketty's Capital in the Twenty-First Century, in particular his recommendation to increase the taxation of wealth and income. The chapter investigates the main argumentative strategies used for and against Piketty's proposal in a corpus of print media articles from four countries. The authors argue that policy problems such as inequality are not merely material or inevitable but are partly maintained through discursive strategies that legitimise this situation and help 'proximate' particular issues in the mind of the reader. Their findings reveal five main discursive strategies: authorisation, rationalisation, moralisation, portrayal of victimhood and inevitability in relation to economic perspectives and linguistic features. One salient outcome is that even those (minority of) articles which are positive about the proposed taxation of wealth are still highly sensitive to counter arguments about the superiority of marketisation, thereby leaving largely uncontested the hegemony of a neoliberal orthodoxy. This is in stark contrast to the negative reactions to Piketty's policy proposals, which heavily use linguistic resources and socio-economic arguments that make sure that the dangerousness, impossibility and inefficiency of higher taxation are conveyed to the reader.

Chapter 9 presents the theoretical underpinnings of historical ethnography in the analysis of policy discourse and examines key methodological considerations in a case study investigating Slovenian language policy. Kristof Savski synthesises discursive, ethnographic and historiographic theoretical approaches in order to investigate policy-making processes despite having no direct access to the 'backstage' of political deliberations. The case study investigates the complex political and institutional dynamics behind the development of a National Language Policy Program 2014-2018 adopted by the Slovene government in order to set a common agenda for state institutions. Data comprise publicly available official and unofficial (e-mail) documents, media texts, and personal narratives obtained through interviews with key actors involved in the policy process. The analysis traces policy construction and implementation processes through discursive analysis of texts and their co-texts (observed changes in different versions of the same document), video-taped sessions of parliament and specialised committees, and through interviews. Historiography helped to reconstruct the full history of the policy in its socio-historical context. Savski thus presents the reader with a multi-layered approach to CDA which is able to unpick the complexity of texts, institutional and social practices, and social agents, thereby revealing underlying power struggles at each moment in the diachronic history of the construction and implementation of policy. 
In Chapter 10, Daniela Caterina integrates Historical Materialist Policy Analysis (HMPA) and the CDA of practical argumentation (Fairclough and Fairclough, 2012) in the analysis of hegemony struggles arising from the Italian government's attempts at crisis management in 2011-2012. The particular case study examined in this chapter focuses on the conflict over the labour market reform introduced by the government of Mario Monti in 2012. Viewing the state as a complex of social relations, HMPA offers a means of systematically integrating the material and the discursive by combining detailed, multi-level, contextual analysis with analysis of agents and processes. By combining it with CDA, she is able to demonstrate how conflict over this policy played a crucial role in Italy's political economy, significantly shifting the balance of political power. Caterina also demonstrates how each approach adds strength to the other. CDA helps to reveal argumentation strategies, while uncovering differences within seemingly similar arguments and policies, which would otherwise go undetected. HMPA provides a rich theory on material context, such as the distinction between hegemony and political projects, which enables CDA to achieve its goal of explanatory critique by going beyond textual analysis to an exploration of the precise relationship between semiotic and extra-semiotic elements of the object(s) of research.

In Chapter 11 Tom Bartlett investigates the differential construction of discourses by a fishing-dependent community in the Western Islands of Scotland and by national and transnational governmental bodies. This particular case study examines ongoing negotiations over fishing rights and the local management of marine resources. In an attempt to mitigate historic distrust of policy officials, Scottish National Heritage (SNH) has involved community groups on the island of Barra to formulate a local management plan under SNH control. Progress has been limited and the chapter investigates whether the problem may be the result of communicating at different scales or whether both discourses are actually incommensurate. To do so, Bartlett employs scales theory (Blommaert 2007) as a nuanced approach to the analysis of how power is dispersed across multiple times, spaces, and scales. The chapter explores semiotic dimensions like voice, norms and values, and the scope of communicability of texts, while also examining material realities, such as diminishing marine resources and the embedding of Scottish governance structures in the UK and EU. The analysis highlights the role of unequal distributions of resources and the polycentric nature of knowledge systems in creating the conditions for 'incommensurate discourses'.

Chapter 12 contains the conclusions and reflects on the achievement of the aims of the volume, the main features of the content and refers to suggestions for future research as formulated in various chapters. 


\section{ACKNOWLEDGEMENTS}

Bringing together a volume such as this is seldom the work of the editors only. It has been in many ways an iterative process, which gained meaning as we were going. The process of gradually receiving and editing the chapters helped us gain an improved insight as to what the volume gradually came to be and its significance for the fields we hoped to contribute to: CDA and CPS. This very process was enriched through the intensive interaction between the editors of the volume and the authors of the various chapters. All authors have played a significant role as peer reviewers to each other's chapters, which has not only helped to significantly raise the quality of all chapters, but also helped improve the consistency and connections between the chapters. Occasionally this slowed down the rhythm of compiling the volume, as new insights generated further rounds of modifications to the chapters. We therefore wish to thank the authors for their patience and constructive feedback throughout this process, with particular thanks to Daniela Caterina for her extensive contributions. We would also like to thank the blind reviewers of our proposal, for their highly useful recommendations for the focus of the volume. Finally, we wish to thank Harry Fabian, our editor at Edward Elgar Publishing, for his constructive and helpful attitude throughout the process.

\section{NOTES}

1. See also Hyatt, 2013, on a framework for investigating education policy discourse, and Fairclough, 2013 for an earlier argument on the potential place of CDA in critical policy studies.

2. For the purposes of this volume we use 'Critical Discourse Analysis' as the umbrella term to denote the variety of approaches within this movement, and the core theoretical principles they share (see Wodak and Meyer 2016, pp. 4-5 for an overview and details).

3. We define 'semiosis' as the set of resources from which meaning(s) can be produced, including - but not limited to - text, discourse, typography, accent and gesture, visual images, and visual design.

4. Following Fraser (1993), political imaginaries can be understood as the taken-for-granted assumptions, values, discourses and beliefs about the problems in society, as well as about how and by whom they should be addressed.

5. This form of explanatory critique is most closely associated with the version of CDA developed by Norman Fairclough (Fairclough, 2003, 2005, 2015; see also Fairclough and Fairclough, 2012).

6. See Farrelly (2019) for an account of how to systematically operationalise this important, yet often ill-defined, analytical concept.

7 We organise our discussion of CDA according to a series of 'approaches'. However, this is largely a matter of convenience, and we are mindful of the reductive dangers associated with applying labels of this kind to what in fact are diverse bodies of work. 
8. In order to protect the identity of the staff members who took part in this research, the real names of these NGOs have been replaced with pseudonyms.

\section{REFERENCES}

Bartlett, T. (2014). Analysing Power in Language: A Practical Guide. London: Routledge.

Bevir, M. and Rhodes, R. (2002). Interpretive theory. Theory and Methods in Political Science 1(1). Available online at: https://escholarship.org/uc/item/ 0bk3k2nq [Accessed 15 March 2019].

Bevir, M. and Rhodes, R. (eds) (2016). Routledge Handbook of Interpretive Political Science. London: Routledge.

Bhaskar, R. (1986). Scientific Realism and Human Emancipation. London: Verso.

Blommaert, J. (2007). Sociolinguistic scales. Intercultural Pragmatics 4(1): $1-19$.

Chouliaraki, L. and Fairclough, N. (1999). Discourse in Late Modernity: Rethinking Critical Discourse Analysis. Edinburgh: Edinburgh University Press.

CMA (2016). Energy market investigation: Final report. Available online at: https://assets.publishing.service.gov.uk/media/5773de34e5274a0da3000113/ final-report-energy-market-investigation.pdf [Accessed 12 January 2019].

Fairclough, I. and Fairclough, N. (2012). Political Discourse Analysis: A Method for Advanced Students. London: Routledge.

Fairclough, N. (1989). Language and Power. London: Longman.

Fairclough, N. (1992). Discourse and Social Change. Cambridge: Polity Press. Fairclough, N. (1995). Critical Discourse Analysis. London: Longman.

Fairclough, N. (2003). Analysing Discourse: Textual Analysis for Social Research. London: Routledge.

Fairclough, N. (2005). Critical discourse analysis and change in transdisciplinary research, in R. Wodak and P. Chilton (eds) A New Agenda in (Critical) Discourse Analysis: Theory, Methodology and Interdisciplinarity, pp. 53-70. Amsterdam: John Benjamins.

Fairclough, N. (2013). Critical discourse analysis and critical policy studies. Critical Policy Studies 7(2): 177-197.

Fairclough, N. (2015). Language and Power (3rd edn). London: Routledge.

Fairclough, N. and Graham, P. (2002). Marx as a critical discourse analyst: The genesis of a critical method and its relevance to the critique of global capital. Estudios de Sociolinguistica 3(1): 185-229.

Fairclough, N. Jessop, R. and Sayer, A. (2004). Critical realism and semiosis, in J. Joseph and J. Roberts (eds) Realism Discourse and Deconstruction, pp. 23-42. London: Routledge. 
Fairclough, N., Mulderrig, J. and Wodak, R. (2011). Critical discourse analysis, in T. Van Dijk (ed.) Discourse Studies: A Multidisciplinary Introduction, pp. 357-378. London: Sage.

Fairclough, N. and Wodak, R. (2008). The Bologna process and the knowledge-based economy: A critical discourse analysis approach, in B. Jessop, N. Fairclough and R. Wodak (eds) Education and the Knowledge-Based Economy in Europe, pp. 109-126. Amsterdam: Sense Publishers.

Farrelly, M. (2015). Discourse and Democracy: Critical Analysis of the Language of government. London: Routledge.

Farrelly, M. (2019). Rethinking intertextuality in CDA. Critical Discourse Studies. Available online at: https://doi.org/10.1080/17405904.2019 .1609538 [Accessed 17 March 2019].

Farrelly, M. (in press). Critical discourse analysis, in P.A. Atkinson, S. Delamont, M.A. Hardy and M. Williams (eds) SAGE Research Methods Foundations. London: Sage.

Finlayson, A. (2007). From beliefs to arguments: Interpretive methodology and rhetorical political analysis. The British Journal of Politics and International Relations 9(4), 545-563. Available online at: https://doi.org/ 10.1111/j.1467-856x.2007.00269.x [Accessed ?].

Fischer, F. (2003). Reframing Public Policy: Discursive Politics and Deliberative Practices. Oxford: Oxford University Press.

Fischer, F. (2007). Deliberative policy analysis as practical reason: Integrating empirical and normative arguments, in F. Fischer, G. Miller and S. Mara (eds) Handbook of Public Policy Analysis: Theory, Politics and Methods, pp. 223-236. Boca Raton: CRC Press.

Fischer F. and Forester, J. (eds) (1993). The Argumentative Turn in Policy Analysis and Planning. Durham, NC: Duke University Press.

Fischer, F. and Gottweis, H. (eds) (2012). The Argumentative Turn Revisited: Public Policy as Communicative Practice. Durham, NC \& London: Duke University Press.

Fischer, F., Torgerson, D., Durnová, A. and Orsini, M. (2015). Introduction to critical policy studies, in F. Fischer, D. Torgerson, A. Durnová and M. Orsini (eds) Handbook of Critical Policy Studies, pp. 1-24. Cheltenham, UK and Northampton, MA, USA: Edward Elgar Publishing.

Flowerdew, J. and Richardson, J. (eds) (2018). The Routledge Handbook of Critical Discourse Studies. Oxon, New York: Routledge.

Fraser, N. (1993). Clintonism, welfare, and the antisocial wage: The emergence of a neoliberal political imaginary. Rethinking Marxism: A Journal of Economics, Culture and Society 6(1): 9-23.

Glynos, J. and Howarth, D. (2007). Logics of Critical Explanation in Social and Political Theory. London, New York: Routledge. 
Hajer, M. and Wagenaar, H. (eds) (2003). Deliberative Policy Analysis: Understanding Governance in the Network Society. Cambridge: Cambridge University Press.

Halliday, M.A.K. and Matthiessen, M.I.M. (2014). An Introduction to Functional Grammar (3rd edn). London/New York: Routledge.

Harvey, D. (1996). Justice, Nature and the Geography of Difference. Oxford: Blackwell.

Hay, C. (1996). Re-stating Social and Political Change. Buckingham: Open University Press.

Hay, C. (2004). The interpretive approach in political science: A symposium 1 (with A. Finlayson, M. Bevir, R. Rhodes and K. Dowding). The British Journal of Politics and International Relations 6: 129-164. DOI: 10.1111/j.1467-856X.2004.t01-6-00131.x.

Hellman, M., Monni, M. and Alanko, A. (2017). Declaring, shepherding, managing: The welfare state ethos in Finnish government programmes, 1950-2015. Research on Finnish Society 10: 9-22.

Hyatt, D. (2013) The critical policy discourse analysis frame: helping doctoral students engage with the educational policy analysis, Teaching in Higher Education, 18:8, 833-845, DOI: 10.1080/13562517.2013.795935.

Kress, G. and Van Leeuwen, T. (2001). Multimodal Discourse: The Modes and Media of Contemporary Communication. London: Arnold.

Jessop, B. (2002). The Future of the Capitalist State. Cambridge: Polity.

Jessop, B. (2004). Critical semiotic analysis and cultural political economy. Critical Discourse Studies 1(2): 159-174.

Jessop, B. (2010). Cultural political economy and critical policy studies. Critical Policy Studies 2(3-4): 336-356.

Laclau, E. and Mouffe, C. (1985/2001). Hegemony and Socialist Strategy (2nd edn). London: Verso.

Lemke, J. (2005). Textual Politics: Discourse and Social Dynamics (2nd edn) London: Taylor and Francis.

Lemke, T. (2012). Foucault, Governmentality, and Critique. London: Routledge.

Machin, D. and Mayr, A. (2010). How To Do Critical Discourse Analysis: A multimodal introduction. London: Sage.

Machin, D. and Mayr, A. (2013). Personalising crime and crime-fighting in factual television: An analysis of social actors and transitivity in language and images. Critical Discourse Studies 10(4): 356-372.

Montesano Montessori, N. (2011). The design of a theoretical, methodological, analytical framework to analyse hegemony in discourse. Critical Discourse Studies 8(3): 169-181.

Mulderrig, J. (2009). The Language of Education Policy: From Thatcher to Blair. Saarbucken: VDM Dr Muller Verlag. 
Mulderrig, J. (2011). The grammar of governance. Critical Discourse Studies 8(1): 45-68.

Mulderrig, J. (2012). The hegemony of inclusion: A corpus-based critical discourse analysis of deixis in education policy. Discourse and Society 23(6): 701-728.

Mulderrig, J. (2015). 'Enabling' participatory governance in education: A corpus-based critical policy analysis, in P. Smyers, D. Bridges, N. Burbules and M. Griffiths (eds) International Handbook of Interpretation in Educational Research, pp. 441-470. Dordrecht: Springer.

Newman, J. and Clarke, J. (1994). Going about our business? The managerialization of public services, in J. Clarke, A. Cochrane and E. McLaughlin (eds) Managing Social Policy, pp. 13-31. London: Sage.

Ofgem (2017). State of the Energy Market Report. Available online at: https:// www.ofgem.gov.uk/system/files/docs/2017/10/state_of_the_market_report 2017_web_1.pdf [Accessed 12 January 2019].

Pearce, M. (2004). The Marketization of Discourse about Education in UK General Election Manifestos. Text 24(2): 245-265.

Pollit, C. (1990). Managerialism and the Public Services: Cuts or Cultural Change in the 1990s? Oxford: Blackwell.

Reisigl, M. (2018). The discourse-historical approach, in J. Flowerdew and J.E. Richardson (eds) The Routledge Handbook of Critical Discourse Studies, pp. 44-59. Oxon, New York: Routledge.

Reisigl, M. and Wodak, R. (2001). Discourse and Discrimination: Rhetorics of Racism and Antisemitism. London: Routledge.

Reisigl, M. and Wodak, R. (2016). The discourse-historical approach (DHA), in R. Wodak and M. Meyer (eds) Methods of Critical Discourse Studies (3rd edn), pp. 23-61. London: Sage.

Schatz, E. (ed.) (2009). Political Ethnography. Chicago: University of Chicago Press.

Sum, N-L. and Jessop, B. (2013). Towards a Cultural Political Economy. Cheltenham, UK and Northampton, MA, USA: Edward Elgar Publishing.

Sum, N.-L. and Jessop, B. (2015). Cultural political economy and critical policy studies: Developing a critique of domination. In F. Fischer, D. Torgerson, A. Durnová and M. Orsini (eds) Handbook of Critical Policy Studies, pp. 128-150. Cheltenham, UK and Northampton, MA, USA: Edward Elgar Publishing.

Torgerson, D. (2015). Harold D. Lasswell and critical policy studies: The threats and temptations of power, in F. Fischer, D. Torgerson, A. Durnová and M. Orsini (eds) Handbook of Critical Policy Studies, pp. 27-46. Cheltenham, UK and Northampton, MA, USA: Edward Elgar Publishing. 
Van Brussel, L., Carpentier, N. and de Cleen, B. (eds) (2019). Communication and Discourse Theory: Collected Works of the Brussels Communication and Discourse Theory Group. Chicago: University of Chicago Press.

Van Leeuwen, T. (1995). Introducing Social Semiotics. London, New York: Routledge.

Van Leeuwen, T. (1996). The representation of social actors, in C.R. Caldas-Coulthard and M. Coulthard (eds) Texts and Practices, pp. 32-70. London and New York: Routledge.

Van Leeuwen, T. (2007). Legitimation in discourse and communication. Discourse and Communication 1(1): 91-112.

Van Leeuwen, T. (2008). Discourse and Practice: New Tools for Critical Discourse Analysis. Oxford: Oxford University Press.

Wagenaar, H. (2011). Meaning in Action: Interpretation and Dialogue in Policy Analysis. London/New York: Routledge.

Wodak, R. (2009). Politics as Usual: The Discourse of Politics in Action. London: Palgrave.

Wodak, R. (2015). The Politics of Fear: What Right-wing Populist Discourses Mean. London: Sage.

Wodak, R. and Meyer, M. (eds). (2016). Methods of Critical Discourse Studies (3rd edn). London: Sage.

Wodak, R. and Krzyżanowski, M. (eds) (2008). Qualitative Discourse Analysis in the Social Sciences. Basingstoke: Palgrave Macmillan.

Yanow, D. (2000). Conducting Interpretive Policy Analysis. Thousand Oaks, CA: Sage.

Yanow, D. (2007). Interpretation in policy analysis: On methods and practice, CriticalPolicyStudies 1(1):110-122.DOI:10.1080/19460171.2007.9518511.

Yanow, D. (2014). Interpretive analysis and comparative research, in I. Engeli and C. Rothmayr (eds) Comparative Policy Studies: Conceptual and Methodological Challenges, pp. 131-159. London: Palgrave Macmillan. 